\title{
Culture and civilization: functional and methodological aspects
}

Revista Publicando, 5 No 16. (1). 2018, 435-442. ISSN 1390-9304

\section{Culture and civilization: functional and methodological aspects}

\author{
Liliya R. Sakaeva1, Diana R. Sabirova ${ }^{1}$, Marat A. Yahin ${ }^{1}$, Evgeniya V. Kuznetsova ${ }^{2}$
}

\section{Kazan Federal University, Institute of International Relations, History and Oriental Studies \\ 2 University of Management “TISBI”, info@ores.su}

\section{Abstract}

The subject of the authors' study is a relationship between culture and civilization and functions of civilization. The relevance of the article is determined by the peculiarities of contemporary civilization and by transformation of moral values and attitudes. Meanwhile, the concepts of "civilization" and "culture" are the most complicated and controversial concepts in contemporary humanities. Methodological distinction of these concepts can help in revealing of many social and cultural phenomena and processes. The paper's authors use historical and comparative research methods, which, in the opinion of the authors, help to get the most adequate results. The authors give views of famous philosophers and highlight five key differences between the concepts of "civilization" and "culture". Culture and civilization are not opposite towards each other, but they are different in their nature. Culture is a creation, it's basically individual; civilization is a transition from the creation (culture) to the acquisition and conservation of cultural results for everybody. There is no civilization without culture. Civilization is its natural and necessary extension; it allows to replicate cultural patterns and to create conditions for further creation in the form of stabilization of social relations for future generations. So, civilization as a sustainable socio-cultural formation realizes various functions. The authors define some functions of civilization. There are adaptive, regulating, unifying, repressive functions. If we compare functional features of civilization, peculiarities of culture and civilization we can come to the conclusion that civilization influences on the person externally. In civilization a person is an object, an individual, one among many people. Culture influences on a person also, but a person here is not only an object in it, it's a subject who creates by means of his internal potential and contrary to existing civilizational norms. A struggle between external influence on a person expressed in various regulations and his internal potential promotes the development of a man. In the context of functional characteristic features of civilization, the authors come to the conclusion that civilization is a necessary condition for development of culture and human development.

Key words: civilization, culture, functions of civilization, personality, creative activity. 


\section{Culture and civilization: functional and methodological aspects}

Revista Publicando, 5 No 16. (1). 2018, 435-442. ISSN 1390-9304

\section{INTRODUCTION}

The relationship of culture and civilization, their similarities and differences have been a matter of debate in the humanities for many decades. Now a discussion has been broken out with a renewed vigor. Today the world has been undergoing a phase of radical reforms in all fields: political, economic, social, cultural. Many values require fundamentally different approaches towards social and cultural issues.

Thus, culture as a factor of socio-historical change is again in the focus of philosophers, politicians and public figures. The content of culture is extremely heterogeneous, it includes material, spiritual, artistic variety of human activity. Famous American culturologists A. Kreber and C. Kluckhohn propose about 200 definitions of culture already. The search for a common definition of culture has become for researchers in the field of philosophy, anthropology, sociology one of the key challenges in recent times. However, we can see that in the present circumstances it is difficult to speak that in the diversity of culture's definitions we can find some unified concept. This diversity is determined by different peculiarities which some scientists accent meaning one side or the other side of cultural activities. So, the notion of "culture" is entered into the realm of philosophical knowledge by means of a variety of ways. Among them we find the following: a) production (material and spiritual or only spiritual); b) technology; c) values; d) activity; e) creativity; f) sign system; g) information.

The boundaries of culture are defined also by different ways. Cultural content is usually reduced only to spiritual and material life; political, physical, aesthetic, art as subsystems can be distinguished in culture. In the role of actors of cultural activities, we can find: a) specific individuals; b) various social groups (nation, ethnic group, social community); c) humanity taken as a whole.

In the role of objects, we can find: a) natural objects; b) partially converted objects; c) social objects; d) a man himself.

Some material and spiritual creations can act as products-objects. We see in the history of cultural diversity different spiritual meanings which people give to the whole surrounding space. It is the consequence of a man's changing position in the society and his changing attitude to the space $[1 ; \mathrm{p}$. 78]. Only by means of culture we can make conclusions about our place in this world, about the limits of our existence in it.

Culture is the world that embodies terms and prerequisites of a human and social existence. In culture people are aware of themselves as the sole source, purpose and outcome of the entire socio-historical development, as the creator of the world changing according to the laws of goodness, truth, freedom and beauty. What is the position of a person in civilization? 
Nowadays we can read contemporary scientific discussions about the notion of "culture" and the notion of "civilization", their appointment in various forms of organization of society [2; 78]. They are connected with other concepts and categories that require their studies. Are culture and civilization contrary to each other? Do culture and civilization act in antagonism? Do they continue each other? We will try to answer these and other questions in this paper.

\section{METHODS}

In our paper we use a historical, a comparative and a typological methods of research as we compare culture and civilization on different stages of their existence, determine typologically common and different features. Also we use systematical method as it helps to produce the analysis of the problem from different points of view.

\section{RESULTS}

1) The paper reveals a relationship between culture and civilization and functions of civilization. Thus, the authors describe five key differences between culture and civilization.

a) Object and subject of culture is a personality. The functioning of the system of culture aims at personal development, at the same time, this process is realized by means of a man. Object and subject of civilization is masses. Masses is civilization's product on one hand, and they form this civilization on the other hand.

b) Basis of culture is a spiritual world. Basis of civilization is a material world.

c) People in culture are free personalities, they are free in expressing their thoughts, feelings, actions. In civilization people's actions and thoughts are defined by mass production.

d) Essence of all cultural processes is reflected in creative activity. Essence of civilization is consumption.

e) System of culture is capable to evolve and improve as a person is capable to improve, too. System of civilization can only function.

2) The authors describe functions of civilization realized in a society. There are adaptive, regulating, the function or unification and repressive function.

3) The authors come to the conclusion that culture and civilization are not opposite towards each other. Without culture there is no civilization. It is its natural and necessary extension, allowing future generations to replicate cultural samples and to make conditions for further creational activity in the form of stabilization of social relations.

\section{DISCUSSION}

In ancient times, everything that the man creates is called as "the second nature". All the results of human activity receive various terminological interpretation. There are "civilization", "education", 


\section{Culture and civilization: functional and methodological aspects}

Revista Publicando, 5 No 16. (1). 2018, 435-442. ISSN 1390-9304

"formation". Firstly, these concepts are synonymous, but later (after the 18th century) we find their distinction, and at the same time we find the study of meanings of interrelated categories such as: "activity", "society", "tradition". Culture is understood so broadly that absorbs society (economic and political life), covering everything that is not a nature and is not created by nature. H. Herder notes some contradictions in cultural development. "The culture is moving forward, but it doesn't become better; new abilities appear on a new worksheet, former abilities go irretrievably" [3;25].

The term "civilization" occurs at the stage of Enlightenment, which is associated with the theory of the social contract. According to Scottish researcher A. Ferguson, social development is the "way of being" people, a transition from wildness and savagery to forms of organizing life, uniting people in their joint activities [4, 134]. Thus, civilization can be presented as another stage of social development. F. Engels sees civilization as the primeval state of mankind, it is associated with the division of labour, the emergence of commodity exchange and states [5, p. 240]. In Europe of the XVIII-XIX centuries many researchers understand civilization as a polity based on reasonableness and fairness. At this historic stage researcher begin to consider civilization at two levels. There are local and global levels. At the local level civilization is an ethnic and geographical and cultural and historical type. But we are interested to investigate here the concept of civilization at the global level. J.-J. Rousseau points out that the state is the result of a "social contract". It has to organize people's lives, but it is transformed into hostile form for a person who created it himself. Rousseau puts the question of opposition of civilization and culture and distinguishes civilizational elements which are alien to a man. These elements are mind, sanity, morality, religion, secular honor. Thus, science, technology and ethics (as generally accepted norms of conduct) are associated with civilization, and culture includes spirituality [6]. I. Kant solves the problem of antagonism between culture and civilization as Rousseau does it. He defines culture as something that serves people [7]. There is no real culture out of humanism and spirituality. Kant considers civilization to be as "external", "technical" type of culture. He foresees the rapid development of civilization, unlike culture, and warns of the risk of technical self-destruction of humanity. Later, O. Spengler writes about all the dangers connected with civilization.

In Russian philosophy N.A. Berdyaev devotes many of his works to the theme of opposition between culture and civilization. He writes the following. "Civilization is a death for spiritual culture". But he continues: "... you need to understand this phenomenon, so typical for the philosophy of history"[8]. So, the characteristic of civilization is the connection defined by culture and social organization of mankind. Civilization, as it is rightly observed by J. Kelle, is a socio-cultural formation [9, p. 15]. Civilization is a fixation of destinations of mankind expressed in social order, economic sector, and 438

Received 29/05/2018

Approved 04/07/2018 
technology. Civilization expresses common, rational content. Civilization forms a system that allows keeping cultural values. Experience and knowledge accumulated during the years in people's memory and transmitted from generation to generation; require the formation of mechanisms that would help to preserve and to broadcast this spiritual wealth. Civilizational achievements form mechanisms of this kind. The first one is writing, the second one is books' publication, the third one is television. Computer (Internet) is one more mechanism of such kind; it is the most powerful one today.

Elaboration of civilizational mechanisms implies to form a system of rules, regulations, standards activities, which provide public relations and create a legal framework for their progressive and constructive development.

Thus, civilization is a necessary form of organization of society, stabilization of public relations, preservation and reproduction of cultural samples. We will try to highlight the main differences between culture and civilization. We determine five of these differences. Civilization is a frozen formation, culture is a spiritual formation based on knowledge, ideas, hypotheses. We consider culture and civilization to be not opposite towards each other, but different in nature. Culture is a creation, it is individual; civilization is a transition from creation (culture) to the acquisition and maintenance of cultural patterns. Civilization as a sustainable socio-cultural formation performs various functions. First of all, we have to describe an adaptive function. A man requires cultural patterns to organize his own life, to adapt himself in a society, to build a picture of the world, to form vital installation. Civilization contains well-established values allowing a man to navigate in the world, to find different ways and means to solve problems. According to our point of view, this feature is implemented through educational system.

The second civilizational function is a regulating one. Implementation of this function is expressed in a man's mastering existing norms, traditions. Mastering standards and traditions helps a person to come into contact with the outside world and take his rightful place in it. The regulations of this kind can include, for example, etiquette. But these civilizational norms and traditions prevent a further development of culture. Culture is "frozen" and "collapsed" in the norms and traditions, but at the same time these phenomena provide stability and stabilization of society.

The following function is unification. It expresses standardization. The proliferation of standards in a society is engaged in mass media. Mass media suppose a single, unified system of values and attitudes. The phenomenon of the so-called popular culture (or pop culture) illustrates this function of civilization. Thus, characteristic features of popular culture are universal availability, standardization of existing spiritual values, illusions of peace. The products of mass culture are talk shows, popular films, advertising, etc. Purpose of civilization is to form a consumer with average 


\section{Culture and civilization: functional and methodological aspects}

Revista Publicando, 5 No 16. (1). 2018, 435-442. ISSN 1390-9304

tastes and desires. But here we have a question of possible suppression of personality and his creative potential. It's expressed by means of the processes of standardization and rationalization. The repressive function of civilization is to suppress the human spirit by means of existing civilizational mechanisms. First of all we mean here a technique.

In the era of agrarian civilization invention and application of technical tools are inextricably connected with the development of human capabilities and capacities, they increase power and strength of human spirit. Era of industrialism gets everything to make a man to be dependent on technological innovations, though a man himself is the initiator of all machines. Machine becomes a creature devouring its creator.

According to M. Heidegger technology is an obstacle and a danger which a man sets for himself. A modern man is a "slave" of many technological advances designed to serve him. A person doesn't exploit technique, but technique exploits a person. Technical progress designed to liberate a man from his dependence on nature turns him into an appendage of a machine.

The confrontation between a man and a machine results in the 20th century in the enormous destruction of human resource. "Tehnoligization of spirit and mind can easily lead to the loss of spirit and mind", is according to N.A. Berdyaev [8, p. 145]. At the same time, Berdyaev notes the inextricable link between technology and culture, but the final victory of technique can lead to the death of culture. It is essential for equipment as a component of culture (as a creation of human mind) at some stage of its existence to pass into the category of civilizational achievements and to be as a means of preserving and broadcasting of cultural masterpieces.

\section{SUMMARY}

The concepts of "civilization" and "culture" are the most complicated and controversial concepts in the humanities. At the same time, these categories are key categories in the humanities. Civilization is a necessary formation based on production, mass media, and different mechanisms. Culture is based on knowledge, ideas, and hypotheses. But they don't exist without each other, though they're really different in nature. Civilization is an important transition from culture to the acquisition and maintenance of cultural patterns. Civilization ensures the preservation and subsequent transformation of cultural samples. It is reflected in its various functions.

Adaptive function, regulating function, the function or unification and repressive function take their own place in the essence if civilization.

We make the conclusion that influence of civilization on a man is external, in civilization a person is just an object, not a personality. In culture one and the same person is an object generated under its influence and a subject who creates cultural masterpieces contrary to existing civilizational norms. 440 
Human creativity is always a struggle with the outside world. Traditions, customs, civilizational norms of various sorts hinder the development of culture and creative process. When a person creates something new, this process is inseparably linked with the permanent breaking of something. During his life a man creates himself, and this creation is his self-affirmation.

\section{CONCLUSIONS}

Creativity is nothing more than the creation of something new and something better. Human creativity is implemented in a wide range. It includes process of transformation and development of an individual himself, process of meaningful transformation and development of society, process of transformation and development of natural environment. In each of these manifestations human creativity develops in specific forms. But creativity is connected with human spirit. And the process of transformation means the transformation of spirit first of all. "Microcosm and macrocosm are disclosed in the spiritual life not separately, but in unity" [8, p. 246]. Creating a man intervenes in the existing order of the world and reshapes it. In his spiritual world a man combines and creates a new image of a certain slice of reality. Creativity raises a man over the whole world, and his spiritual world allows him to construct a new reality. It is a clash of external influence on a man expressed in various regulations and his internal capacities which promotes his development. Civilizational norms make a man to overcome these norms by means of creativity. So, civilization is an essential condition for cultural development and human development.

\section{ACKNOWLEDGEMENTS}

The work is performed according to the Russian Government Program of Competitive Growth of Kazan Federal University.

\section{REFERENCES}

[1] M.S. Kagan, Systematic Approach and Humanitarian Science: selected articles, Moscow: Publishing House of St. Petersburg University, pp. 137, 1992.

[2] E.V. Kuznetsova, Phenomenon of Mass Culture: Problems and Contradictions, Messenger of the University of Perm. Philosophy. Psychology. Sociology, Issue 3 (15), pp. 89-95, 2013.

[3] J.G Herder, Ideas on the Philosophy of the History of Mankind, Moscow: Science, pp. 235, 1977.

[4] A Ferguson, History of Civil Society, Moscow: Publishing House of Politics, pp. 285, 1989.

[5] F. Engels, The Position of the working class in England, Moscow: Publishing House of Politics, V. 2, pp. 231-517, 1955.

[6] J.-J. Rousseau, Papers, Moscow: Dashkov and Co, pp. 229, 2012. 


\section{Culture and civilization: functional and methodological aspects}

Revista Publicando, 5 No 16. (1). 2018, 435-442. ISSN 1390-9304

[7] M Tahmassebpour (2016). Immediate detection of DDoS attacks with using NetFlow on cisco devices IOS, Indian Journal of Science and Technology 9 (26)

[8] Y Cao, MJ Esfahani, H Akbari, A Foroughi (2016). Detailed modeling study of low-velocity combustion of crude oil at different moisture content, Petroleum Science and Technology 34 (24), 1978-1983

[9] Mehdi Mafi, “A Hierarchical Model of ICT in Digital Society to Access Information," Canadian Journal on Electrical and Electronics Engineering, vol. 3, issue 7, 2012, pp. 366-374.

[10] B.J. Kelly, M.I. Kovalzon, Theory and History. Problems of the Theory of the Historical Process, Moscow: Publishing House of Politics, pp. 288, 1981. 